\title{
曲げ・せん断とねじりを同時に受ける 鉄筋コンクリート部材の耐力と変形 \\ STRENGTH AND DEFLECTION OF REINFORCED CONCRETE MEMBERS SUBJECTED TO COMBINED BENDING, SHEAR AND TORSION
}

岡本享久*・長滝重 義** By Takahisa OKAMOTO and Shigeyoshi NAGATAKI

\begin{abstract}
Theoretical expressions for the ultimate strengths and the deformations of reinforced concrete members subjected to combined bending, shear and torsion are described. They are based on a space truss model. Equilibrium and compatibility are considered and the obtained equations involve the behaviours at ultimate of the concrete struts among diagonal cracks, the locations of centroid of shear flows and the distributions of shear strains at the vertical face where the vertical shear stresses and the torsional stresses are additive and the other vertical face where the vertical shear stress and torsional stresses are subtractive. The proposed equations are compared with test results and good correlation is noted.
\end{abstract}

\section{1. まえがき}

従来，鉄筋コンクリート構造部材の設計に際し，ねじ りモーメントが作用する場合，その影響を二次的な程度 に抑えることを前提としてきた。しかしながら，地震国 特有の問題亡して, 通常の荷重状態ではねじりモーメン トの発生をみないのに，地震時に大きなねじりモ一メン トが構造物に発生し，現実に被害例も報告" dれている ことを考慮すると，ねじりモーメントがコンクリート構 造物の耐力および変形性状に及ぼす影響を定量的にとら えることは重要な課題である.

これらの事情を背景として, わが国でも 1960 年代か らねじりを受けるコンクリート部材の破壊機構に関する 研究が活発化し，純ねじりおよび曲げとねじりを同時に 受ける場合については設計に適用可能なところまで発展 した.しかしながら, 現実の構造物において最も一般的 な荷重状態である曲げ・せん断にねじりが作用する場合 の終局耐力および変形性状に関する理論的および実験的 研究はほとんど見受けられない。この原因として, せん

* 正会員 工修 東京工業大学助手 工学部土木工学科 ( ₹152 目黒区大岡山 2-12-1)

** 正会員 工博 東京工業大学教授 工学部土木工学科 (同上)
断破壊が曲げ破壊に比べて非常に多くの要因を受ける複 雑な破壊であるため，適切なモデル化が行えず数学的な 取扱いが難しいことが挙げられ，したがって，ねじりと せん断を同時に受ける場合は一層複雑な問題となる。著

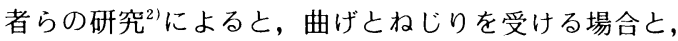
曲げ・ねじりにせん断力が同時に作用する場合を比べる と, せん断力の作用によって約 $30 \%$ もねじり耐力が低 下する場合があり，この種の組合せ荷重下の破壊機構を 知ることは合理的な設計を行うために重要な意義をもつ ものであると考えられる．

したがって，本研究では，曲げ・せん断とねじりを同 時に受ける鉄筋コンクリート部材の耐力および変形性状 を明らかにする目的で解析および実験の両面から検討を 加えた。 すなわち, 解析にあたって, かぶりコンクリー トの耐力に及ぼす影響, 斜めひびわれ間のコンクリート ストラットの挙動およびせん断とねじりによる影響が累 加される側面と相殺される側面の鉄筋とコンクリートの ひずみ分布を考慮して，つり合い条件式およびひずみの 適合条件式を求め，ねじり耐力および変形に関する算定 式を提案した。ここで求められた算定式はねじり耐力お よびせん断耐力に及ぼすパラメーター，すなわちねじり モーメントと曲げモーメントの比, 曲げモーメントとせ ん断力の比, 鉄筋比およびコンクリート強度の影響を含 
んでおり，実験結果を合理的に説明できた。

\section{2. 既往の研究と本論文の特徵}

曲げ・ねじりとせん断を同時に受ける鉄筋コンクリー 卜部材の耐力および変形を理論的に取り扱った論文に使 用されているモデルは,斜め曲げモデルに基づくものと, 立体トラスモデルに基づくものの 2 種に大別される. 現 在までの耐力に関する代表的な研究として, 斜め曲げモ デルを用いたElfren ${ }^{3)}$, Ewida \& McMullen ${ }^{4)}$ の研究が あり，立体トラスモデルを用いたCollins \& Mitchell ${ }^{5}$, Thürlimann ${ }^{61}$ の研究がある.

Ewida \& McMullen は図一1に示す斜め曲げモデル に基づいてねじりとせん断の組合せ荷重を受ける鉄筋コ ンクリート部材の強度およびすべての荷重段階における 変形を予測する解析方法を示している. 解析にあたり, 力のつり合いおよび変形の適合条件を考慮しており, ね じりモーメントにせん断力が同時に作用する場合を取り 扱えること, および荷重-ひずみ関係, 荷重-変形関係を 予測できることに特徴がある. 仮定した破壊面は Elfrenのものと同一であり, 矩形ばりの 3 つの面上で 生ずるらせん状のひびわれと第 4 面において 3 つの面に 生じたひびわれの端部を結ぶ圧縮域から形成されると仮 定している. 破壊モードとして, コンクリートの圧縮域 がおのおの上, 下面にある場合之, 圧縮域が側面にある 場合の 3 種類を考えている. この論文の特徴は引張面で の圧縮面に鉛直なひずみを

$$
\varepsilon_{n \phi}=\varepsilon_{l}\left(\cos ^{2} \phi+\tan \theta \sin \phi \cos \phi\right)
$$

$$
+\varepsilon_{h}\left(\sin ^{2} \phi+\sin \phi \cos \phi / \tan \theta\right)
$$

で表わし,この式（1）と圧縮域の $\phi$ 面に垂直な圧縮 ひずみとのひずみの適合条件を考えることにより，任意 の荷重段階における荷重と変形曲線を求めることができ る. また, 解析上の仮定としてせん断力によるせん断応 力とねじりによるせん断応力が累加される面のひびわれ 角度 $\beta_{1}$ とそれぞれのせん断応力が相殺される面でのひ びわれ角度 $\beta_{2}$ の間には

$$
\tan \beta_{2}=\frac{2-1 / \eta}{2+1 / \eta} \tan \beta_{1}
$$

を使用している。なお，ここで $\eta=T / V b_{1}$ である. 最

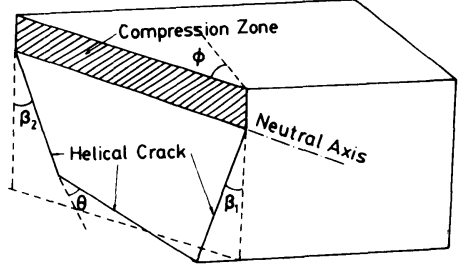

SKEW-BENDING MODEL (MODE 1)

図一1 斜め曲げモデル
終的に終局荷重は荷重-変形曲線の傾きがゼロの荷重と して求めることができる.

Collins \& Mitchell は立体トラスモデルを用いて解析 を行っている. トラス理論の問題点として斜めひびわれ 角度を決定することができないことを補うために， Wagner の引張場の理論の考え方，すなわち座屈後の薄 いウェブは圧縮力を負担せず，せん断力は斜め方向引張 力により伝達されるとし, 斜め方向引張力の角度を決定 するために，この角度は引張主ひずみの向きに一致する という仮定に基づく考え方を導入している.すなわち， コンクリートは引張力を負担せず，せん断力は斜め方向 圧縮力によって伝達されるとして鉄筋コンクリートばり に対してもWagner の考え方を応用し, 王縮場の理論と して，标じりおよびせん断の問題を扱っている．解析上 の仮定として，斜めひびわれ間のコンクリートストラッ トを曲げに関する終局理論と同様に取り扱っているこ と，ねじり耐力に対してかぶりコンクリートの影響を無 視していることが特徴的である.ねじりとせん断の両方 の作用外力を受ける場合の考え方の基本として，ねじり モーメントおよびせん断力によるせん断応力を重ね合わ せた式から，ひびわれ角度を試行錯誤によって求め，鉄 筋の応力を算出する方法について述べているが，この種 の組合せ荷重下の耐力を直接求める方法については触れ ていない. Thürlimann も立体トラスモデルに基づいて, スターラップの降伏後, はりの下面, 上面および側面の おのおのの軸方向鉄筋が降伏する 3 つの破壊形式につい て耐力算定式を導いた。すすなわち,

下面の軸方向鉄筋の降伏に対して

$\frac{F_{y u}}{F_{y l}}\left[\left(\frac{T_{u}}{T_{u 0}}\right)^{2}+\left(\frac{V_{u}}{V_{u 0}}\right)^{2}\right]+\frac{M_{u}}{M_{u 0}}=1$

上面の軸方向鉄筋の降伏に対して

$\left(\frac{T_{u}}{T_{u 0}}\right)^{2}+\left(\frac{V_{u}}{V_{u 0}}\right)^{2}-\frac{F_{y l}}{F_{y u}} \frac{M_{u}}{M_{u 0}}=1$

側面の軸方向鉄筋の降伏に対して

$$
\begin{aligned}
& \left(\frac{T_{u}}{T_{u 0}}\right)^{2}+2 \frac{T_{u}}{T_{u 0}} \frac{V_{u}}{V_{u 0}} \sqrt{2 h / u} \\
& +\left(\frac{V_{u}}{V_{u 0}}\right)^{2}=\frac{1}{2}\left(\frac{F_{y l}}{F_{y u}}+1\right) \ldots \ldots
\end{aligned}
$$

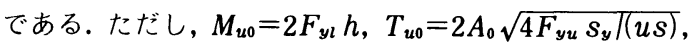
$V_{u 0}=2 \sqrt{2 F_{y u} s_{y} h / s}$ であり, $T_{u}$ : 終局ねじりモ一メン 卜, $M_{u}$ : 終局曲げモーメント, $V_{u}$ : 終局せん断力, $T_{u 0}$ ：終局純ねじりモーメント, $M_{u 0}$ ：終局純曲げモーメント， $V_{u 0}$ : 終局純せん断力, $F_{y l}$ : 下端筋の降伏力, $F_{y u}$ : 上 端筋の降伏力, $s_{y}: 1$ 本のスターラップの降伏力, $u$ : 断面にある軸方向鉄筋が囲む面積の周長, $h$ : 断面の高 さである。

以上のように，2つのモデルに基づく解析があるが, 
それぞれに利点・欠点がある.そこで本研究では立体卜 ラスモデルに基づく方が合理的であると考え，このモデ ルに基づき，曲げ・せん断とねじりを同時に受ける鉄筋 コンクリート部材の耐力および変形性状を解析的に検討 したものであり, 以下の特徴を有する.

（1）曲げ・せん断およびねじりを同時に取り扱い, モデルとして立体トラスモデルを用い,簡単なつり合い条 件およびひずみの適合条件を利用して under reinforced, partially overreinforced, completely overreinforced の場合について解析を可能とした.

（2）従来より純ねじりを受ける場合に使用されてき

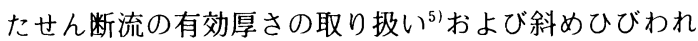
間の斜め圧縮部コンクリートの取り扱い帛を明確にし た。

（3）立体トラス理論は斜めひびわれがはり四面に 入った場合のみ本来適用可能であるが，断面を構成する 上，下面および両側面のひずみ性状およびひびわれ角度 をひずみの適合条件式に応用することにより，曲げ・せ ん断がねじりに比べて卓越する領域まで解析を可能とし た。

\section{3. 構成方程式}

\section{（1）荷重の組合せ}

作用しているねじりモーメント $(T)$, 曲げモーメン ト $(M)$ およびせん断力 $(V)$ の間には次のような関係 があると仮定する.

$$
\begin{aligned}
& f=T / M \\
& g=M / V
\end{aligned}
$$

\section{（2）つり合い条件}

仮定した立体トラスモデルについて図一2に示すよう に作用ねじりモーメントと作用せん断力を仮想外力とし てのせん断流と置き換え，このせん断流と鉄筋およびコ ンクリートの応力とのつり合い式を求めた.

作用ねじりモーメントおよび作用せん断力とせん断流 の関係は,

$$
\begin{aligned}
& q_{T}=T /\left(2 b_{1} d_{1}\right) \\
& q_{V}=V /\left(2 d_{1}\right) \cdots
\end{aligned}
$$

となる。なお， $b_{1}, d_{1}$ はせん断流の通路厚の中心線が 用む断面の幅および高さである。

破壊はねじりモーメントとせん断力による主引張方向 が同一となる側面で生じ，この側面の応力状態が終局耐 力を決定するとすれば，この面におけるコンクリートお よび鉄筋とせん断流とのつり合い条件を考えることによ り, 終局時のせん断流が決定される.すなわち, 図一2(a), (b) に示すように仮想モデルのねじりとせん断による 主引張方向が同一となる面 (A 面) と上下面の左半分 上で斜め玨縮部コンクリートとねじりモーメントとせん
断力によるせん断流との部材軸に垂直方向のつり合いを 考えることによって

$$
f_{c 1}^{l}=\frac{T+V b_{1}}{b_{1} d_{1} t_{d} \sin 2 \alpha^{l}}
$$

が得られ，また図一2 (d) で free bodyについて部材軸 に垂直方向のつり合いにより

$$
f_{h}^{l}=\frac{\left(T+V b_{1}\right) s}{2 b_{1} d_{1} A_{h} \cot \alpha^{l}}
$$

が導かれる.さらに図一2 (c) に示すように，上縁およ び下縁の軸方向鉄筋について，断面の左半分のすべての カのモーメントのつり合いを考えると

$$
\begin{aligned}
f_{l b}^{l}= & \frac{1}{A_{s} d_{0}}\left(\frac{M}{2}+\frac{T d_{1} \cot \alpha^{l}}{4 b_{1}}\right. \\
& \left.+\frac{V d_{1} \cot \alpha^{l}}{4}+\frac{T \cot \alpha^{b}}{4}\right) \\
f_{l t}^{l}= & \frac{1}{A_{s}^{\prime} d_{0}}\left(-\frac{M}{2}+\frac{T d_{1} \cot \alpha^{l}}{4 b_{1}}\right. \\
& \left.+\frac{V d_{1} \cot \alpha^{l}}{4}+\frac{T \cot \alpha^{t}}{4}\right) .
\end{aligned}
$$

を導くことができる.ここで， $t_{d}$ ：仮想壁厚， $f_{c l}$ : 斜 めひびわれ間の斜め圧縮部コンクリートに作用する応 力, $f_{h}$ : 腹鉄筋に作用する応力, $f_{l b}$ : 下板に配筋され た軸方向鉄筋の応力， $f_{l t}$ : 上板に配筋された軸方向鉄 筋の応力, $A_{h}$ : 腹鉄筋 1 本の断面積, $A_{s}$ : 下板に配筋 された軸方向鉄筋の総量の $1 / 2$ の断面積, $A_{s}^{\prime}$ : 上板に 配筋された軸方向鉄筋の総量の $1 / 2$ の断面積, $d_{0}$ : 上 板と下板に配置された軸方向鉄筋の図心間の距離であ る. 各記号の肩文字, $l, r, t, b$ はそれぞれ A 側面, $\mathrm{B}$ 側面, 上面, 下面を示す.

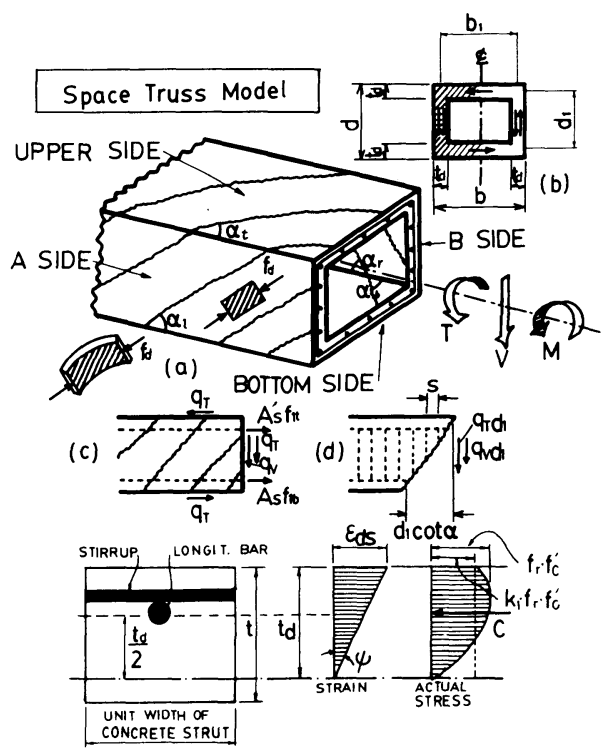

図一2 仮想モデル 


\section{（3） せん断流の通路厚}

せん断流は斜めひびわれ間のコンクリートにおいて, ひびわれ面の垂直方向に一様に分布すると考え, その深 さ方向のせん断流の通路厚 $\left(t_{d}\right)$ は, 図一2 (e) に示す ように矩形分布するとして求めた。すなわち, 式 (10), (11)，（12）および（13）のつり合い式より, $\sin ^{2} \alpha^{l}$, $\cos ^{2} \alpha^{l}$ を求め, 式 (16), （17）を参照すると次式が得 られる。

$$
\begin{aligned}
t_{d}= & \frac{A_{h} f_{h}^{l}}{f_{c l}^{l} s}+\frac{\left(A_{s} f_{l b}^{l}+A_{s}^{\prime} f_{l t}^{l}\right) d_{0}}{f_{c l}^{l} s b_{1} d_{1}} \\
& \cdot \frac{\left(1+b_{1} / f g\right) d_{0}}{\left(d_{1} / b_{1}+d_{1} / f g+k\right)} \cdots \cdots \ldots
\end{aligned}
$$

ここで, $k=\left(\frac{2+b_{1} / f g}{2}+\frac{2}{2+b_{1} / f g}\right) / 2$ である.

\section{(4) 变形の適合条件}

図一2のA 側面上におけるせん断ひずみ $\left(\gamma^{l}\right)$ は，軸 方向鉄筋の平均ひずみ $\left(\bar{\varepsilon}^{l}\right)$ 亡腹鉄筋のひずみ $\left(\varepsilon_{h}^{l}\right)$ お

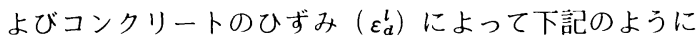
表わされる.

$$
\begin{aligned}
\gamma^{l}= & \bar{\varepsilon}_{l}^{l} / \tan \alpha^{l}+\varepsilon_{h}^{l} \tan \alpha^{l} \\
& +\varepsilon_{d}^{l} /\left(\sin \alpha^{l} \cdot \cos \alpha^{l}\right) .
\end{aligned}
$$

同様に上，下面および B 側面上におけるせん断ひずみ $\left(\gamma^{t}, \gamma^{b}, \gamma^{r}\right)$ も同様に表わされる。ここで, $\bar{\varepsilon}_{l}^{l}=\left(\varepsilon_{l b}^{l}+\right.$ $\left.\varepsilon_{l t}^{l}\right) / 2$ であり， $\varepsilon_{l b}, \varepsilon_{l t}$ はそれぞれ下面，上面の軸方向鉄 筋のひずみである， $\alpha^{l}, \alpha^{r}, \alpha^{t}, \alpha^{b}$ はそれぞれ A 側面, $\mathrm{B}$ 側面および上下面のひびわれ角度である.

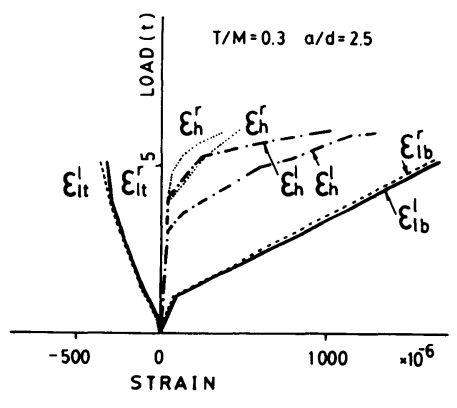

図一3 軸筋とスターラップのひずみ分布

曲げ・せん断およびねじりを受ける場合，軸方向鉄筋 のひずみは図一3に示すように，せん断とねじりによる 主引張方向が同一となる面 (A 側面) と直交する面 (B 側 面）でほぼ同様の挙動を示し， $\varepsilon_{l b}^{l}=\varepsilon_{l b}^{r}, \quad \varepsilon_{l t}^{l}=\varepsilon_{l t}^{r}$ と仮定 する，一方，せん断と站じりを受ける部材の両側面のひ びわれ角度は異なってくる．この傾向は $T / V b_{1}\left(b_{1}\right.$ ： せん断流の通路の中心線が囲む矩形の短辺長）が小なる 領域で起こる。したがって, A 側面と B 側面および A 側面と上下面におけるひびわれ角度と $T / V b_{1}$ の間には
次のような関係 ${ }^{4}$ が成立すると仮定する

$$
\begin{aligned}
& \frac{\tan \alpha^{r}}{\tan \alpha^{l}}=\frac{2+1 / \eta}{2-1 / \eta} \ldots \ldots \ldots \ldots \ldots . . . \\
& \frac{\tan \alpha^{b}}{\tan \alpha^{l}}=\frac{\tan \alpha^{l}}{\tan \alpha^{l}}=\frac{2+1 / \eta}{2}
\end{aligned}
$$

ここで, $\eta=T /\left(V b_{1}\right)$ である.

この式（16）および式（17）は実験結果 ${ }^{2), 91}$ と比較す ると図一4 のようになり，実際の各面におけるひびわれ 角度をよくとらえることができる.

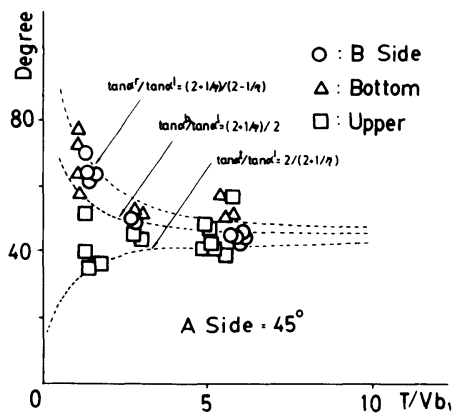

図一4 A 面とその他の面のひびわれ角度の関係

腹鉄筋と斜め圧縮部コンクリートのひずみは，A 側 面と B 側面の断面で式（10）および式（11）より，

$$
\begin{aligned}
& \frac{\varepsilon_{h}^{r}}{\varepsilon_{h}^{l}}=\frac{1-1 / \eta}{1+1 / \eta} \cdot \frac{\tan \alpha^{r}}{\tan \alpha^{2}} \\
& \frac{\varepsilon_{d}^{r}}{\varepsilon_{d}^{l}}=\frac{1-1 / \eta}{1+1 / \eta} \cdot \frac{\sin 2 \alpha^{l}}{\sin 2 \alpha^{r}}
\end{aligned}
$$

となる.さらに, A 側面と上下面で

$$
\begin{aligned}
& \frac{\varepsilon_{h}^{b}}{\varepsilon_{h}^{l}}=\frac{1 / \eta}{1+1 / \eta} \cdot \frac{\tan \alpha^{b}}{\tan \alpha^{l}} . \\
& \frac{\varepsilon_{d}^{b}}{\varepsilon_{d}^{l}}=\frac{1 / \eta}{1+1 / \eta} \cdot \frac{\sin 2 \alpha^{l}}{\sin 2 \alpha^{b}}
\end{aligned}
$$

となる.

式 (18)～式 (21) を，各面のせん断ひずみとひびわ れ角度の関係式に代入し, 式 (16)，(17）の関係を利用 して A 側面のひびわれ角度 $\left(\alpha^{l}\right)$ について整理し, 単 位長さ当たりのねじり角 $(\phi)$ とせん断ひずみの関係式 に代入すると，

$$
\begin{aligned}
& \phi=\frac{d_{1}}{2 A_{0}}\left\{\frac{\bar{\varepsilon}_{l}}{\tan \alpha^{l}} A_{x}+\varepsilon_{h}^{l} B_{y} \tan \alpha^{l}\right. \\
& \left.+\frac{\varepsilon_{d}^{l}}{\sin \alpha^{l} \cos \alpha^{l}} C_{z}\right\}
\end{aligned}
$$

となり,ここで

$$
\begin{aligned}
A_{x}= & 1+\frac{b_{1}}{d_{1}}\left(\frac{2}{2+1 / \eta}+\frac{2+1 / \eta}{2}+\frac{2-1 / \eta}{2+1 / \eta}\right) \\
B_{y}= & 1+\frac{b_{1}}{d_{1}} \frac{1}{1+1 / \eta}\left\{\left(\frac{2}{2+1 / \eta}\right)^{2}\right. \\
& \left.+\left(\frac{2+1 / \eta}{2}\right)^{2}\right\}+\frac{1-1 / \eta}{1+1 / \eta}\left(\frac{2+1 / \eta}{2-1 / \eta}\right)^{2}
\end{aligned}
$$




$$
\begin{aligned}
C_{z}= & 1+\frac{b_{1}}{d_{1}} \frac{1}{1+1 / \eta}\left\{\left(\frac{2}{2+1 / \eta}\right)^{2}\right. \\
& \left.\cdot\left(\frac{1+\tan ^{2} \alpha^{b}}{1+\tan ^{2} \alpha^{l}}\right)^{2}+\left(\frac{2+1 / \eta}{2}\right)^{2}\left(\frac{1+\tan ^{2} \alpha^{b}}{1+\tan ^{2} \alpha^{r}}\right)^{2}\right\} \\
& +\frac{1-1 / \eta}{1+1 / \eta}\left(\frac{2-1 / \eta}{2+1 / \eta}\right)^{2} \ldots \ldots \ldots \ldots \ldots \ldots \ldots \ldots \ldots
\end{aligned}
$$

となる.なお， $\alpha^{\imath}$ は曲げ・せん断・ねじりを受ける場合， 大略 $40^{\circ} \sim 50^{\circ}$ の值をとる2)ので, 式(25)の右辺の第 2 項, 第 3 項を Taylor 展開を用いて簡略化すると,

$$
\begin{aligned}
C_{z}= & 1+\frac{b_{1}}{d_{1}} \frac{1}{1+1 / \eta}\left[\left(\frac{2}{2+1 / \eta}\right)^{2}\right. \\
& \cdot\left\{0.587\left(\frac{2+1 / \eta}{2}\right)^{2}+0.413\right\}^{2}+\left(\frac{2+1 / \eta}{2}\right)^{2} \\
& \left.\cdot\left\{0.587\left(\frac{2}{2+1 / \eta}\right)^{2}+0.413\right\}^{2}\right]+\frac{1-1 / \eta}{1+1 / \eta} \\
& \cdot\left(\frac{2-1 / \eta}{2+1 / \eta}\right)^{2}\left\{0.587\left(\frac{2+1 / \eta}{2-1 / \eta}\right)^{2}+0.413\right\}^{2}
\end{aligned}
$$

外力によって仕事がなされると, 内部エネルギーは最 小を保とうとする．したがって，ある与えられた荷重に 対し，外力による変位は最小となる．このことは $d \phi / d$ $\alpha^{l}=0$ となることであり, 式 (22) より

$$
\tan ^{2} \alpha^{l}=\frac{\varepsilon_{d}^{l} C_{z}+\bar{\varepsilon}_{l} A_{x}}{\varepsilon_{d}^{l} C_{z}+\varepsilon_{h}^{l} B_{y}}
$$

立体卜ラスモデルの斜め圧縮部コンクリートの曲げ変

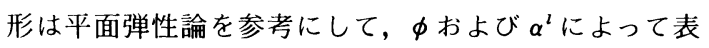
示されると仮定する.

$$
\psi=\phi \sin 2 \alpha^{l}=\varepsilon_{d s} / t
$$

ここで， $\phi$ は斜め圧縮部コンクリートの曲率である.

\section{（5）軸方向鉄筋および腹鉄筋の平均ひずみ}

式 (22)，(26）および（27）を用いて， $\bar{\varepsilon}_{l}$ あるいは $\varepsilon_{h}^{l}$ の值を求め， $\alpha^{l}$ に関する項を式 (10)，(11)，(12) および（13）を用いて消去すると以下のようになる.

$$
\begin{aligned}
\bar{\varepsilon}_{l}= & \frac{1}{2}\left\{-\frac{C_{z}}{A_{x}} \cdot \frac{\varepsilon_{d s}}{2}\right. \\
+ & \left.\sqrt{\left(\frac{C_{z}}{A_{x}} \frac{\varepsilon_{d s}}{2}\right)^{2}+\frac{2 \varepsilon_{d s} A_{0}^{2} f_{c l}^{l}\left(d_{1} / b_{1}+d_{1} / f g+k\right)}{d_{1} A_{x} E_{s} d_{0}\left(A_{s}+A_{s}^{\prime}\right)\left(1+b_{1} / f g\right)}}\right\} \\
\varepsilon_{h}^{l}= & \frac{1}{2}\left\{-\frac{C_{z}}{B_{y}} \cdot \frac{\varepsilon_{d s}}{2}\right. \\
& \left.+\sqrt{\left(\frac{C_{z}}{B_{y}} \cdot \frac{\varepsilon_{d s}}{2}\right)^{2}+\frac{2 \varepsilon_{d s} A_{0} f_{c l}^{l} s}{d_{1} B_{y} A_{h} E_{s}}}\right\}
\end{aligned}
$$

（6）終局時のねじりモーメント，せん断力および曲 げモーメントの算定

式 (10) の $\sin \alpha^{l} \cdot \cos \alpha^{l}$ の項に, 式 (10), (11), (12)

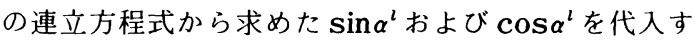
ると

$$
\begin{aligned}
& T_{u}=2 A_{0} \\
& \sqrt{\frac{A_{h} f_{h}\left(A_{s}+A_{s}^{\prime}\right) \bar{f}_{l} d_{0}}{A_{0} s\left(1+b_{1} / f g\right)\left(d_{1} / b_{1}+d_{1} / f g+k\right)}}
\end{aligned}
$$

が求まり, $V_{u}$ も同様にして

$$
V_{u}=\frac{T_{u}}{f g}
$$

となる。

解析で取り扱った式（6) および（7）はねじり, 曲 げおよびせん断の各組合せ荷重間の条件を示す仮定であ り, 式（14）および式（28）－式（31）の值はねじりと せん断の比率の関数として表わされる. したがって, 曲 げ耐力は, 配置された軸方向鉄筋の降伏ひずみから式

（28）で求めた軸方向鉄筋の平均ひずみを差し引いたひ ずみから求めることができると考えられる.したがって,

$M_{u}=f_{b l b} \cdot I_{s} / y_{i}$ or $=f_{u l b} \cdot I_{s} / y_{i}^{\prime}$

ここで $f_{b l b}, f_{t l b}$ は配置した軸方向鉄筋の降伏応力と, 式 (28) のひずみから求めた応力の差であり， $I_{s}, y_{t}$ お よび $y_{i}^{\prime}$ は断面に配置された軸方向鉄筋について考えた 断面二次モーメント, 中立軸から下側および上側の軸筋 までの距離である.

\section{（7）解析上の仮定}

a）終局時の斜め圧縮部コンクリートのひずみ 斜めひびわれ間のコンクリートはそれを横切るスター ラップおよび軸方向鉄筋の影響によって図一 5 に示すよ うな二軸状態の圧縮一引張 ${ }^{7), 81}$ となり，一軸状態のコンク リートに比べて著しく強度が低下する．斜めひびわれ間 のコンクリートの挙動をねじりに関して取り扱った論 文には, 1981 年の Ewida, McMullen ${ }^{4}, 1982$ 年の著者

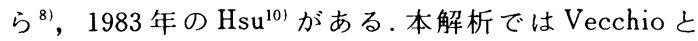
Collins ${ }^{11}$ の考え方を参照して，次式によって斜めひび われ間のコンクリートの応力ーひずみ関係を用いた。

$$
\begin{aligned}
& \sigma_{d}=f_{c}^{\prime}\left[2 \frac{\varepsilon_{d}}{\varepsilon_{0}}+\frac{1}{f_{r}} \cdot\left(\frac{\varepsilon_{d}}{\varepsilon_{0}}\right)^{2}\right], \quad \varepsilon_{d s} \leq \varepsilon_{p} \cdot \\
& \sigma_{d}=f_{p}\left[1-\left(\frac{\varepsilon_{d}-\varepsilon_{p}}{2 \varepsilon_{0}-\varepsilon_{p}}\right)^{2}\right], \quad \varepsilon_{d s}>\varepsilon_{p} \cdots
\end{aligned}
$$

これらの関係は図一6のようになり，ここで $f_{r}$ は低減

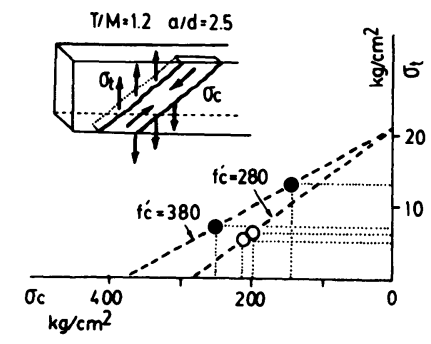

図一5 斜め圧縮部コンクリートの挙動 


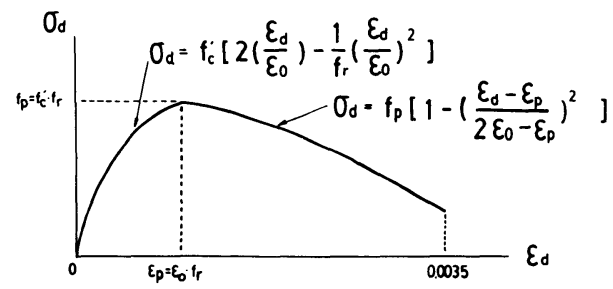

図一 斜めひびわれ間のコンクリートの挙動

係数で以下のような式で表わされる ${ }^{11}$.

$$
f_{r}=1 / \sqrt{\left(\varepsilon_{l}+\varepsilon_{h}+2 \varepsilon_{d}\right) / \varepsilon_{d}-0.3}
$$

斜めひびわれ間のコンクリートの応力・ひずみ関係を矩 形分布（図一2 (e)) に変換することによって一般化す ると

$$
k_{1} \text { =平均応力 }\left(f_{c l}^{l}\right) / \text { ピーク強度 }\left(f_{c}^{\prime} \cdot f_{r}\right)
$$

となり,この $k_{1}$ は式 $(33),(33)^{\prime}$ を積分することによっ て求めることができる.

$$
\begin{aligned}
k_{1}= & \left\{1-\frac{1}{\left(2 / f_{r}-1\right)^{2}}\right\}\left(1-\frac{\varepsilon_{\rho}}{3 \varepsilon_{d s}}\right) \\
& +\frac{1}{\left(2 / f_{r}-1\right)^{2}} \cdot \frac{\varepsilon_{d s}}{\varepsilon_{\rho}}\left(1-\frac{1}{3} \frac{\varepsilon_{d s}}{\varepsilon_{\rho}}\right)
\end{aligned}
$$

本解析では $\varepsilon_{d s}=0.0035 ， \varepsilon_{0}=0.002$ を用いた。なお， ねじりとせん断の組合せ荷重下では $T$ と $V$ の比率が変 化しても，斜めひびわれ間のコンクリートの挙動はほと んぜ変化しないと考えられ， $f_{r}$ は $T / V$ および $T / M$ には無関係と仮定した。

b ) せん断流の通路

せん断流の有効通路の考え方に関し, Collins \& Mitchell $^{51}$ は高荷重下ではかぶりコンクリートが剝離す るために閉合スターラップより外側のコンクリートはね じり耐力に貢献しないとし，閉合スターラップの中心線 より内側にせん断流の通路厚を仮定した．泉 ${ }^{121}$ は解析に あたりせん断流の通路について Collins \& Mitchell ${ }^{5)}$ と 同様に扱っているが，ひびわれ発生後とかぶりコンク リートの剝離後では区別する必要があると指摘してい る. 実験結果 ${ }^{21,91}$ によるとかぶりコンクリートの剝離が 起こるのは最大荷重以後であって, 斜めひびわれ発生か ら鉄筋の降伏する状態では起こらないことが多い。さら に，かぶりコンクリートの剥離は，鉄筋の付着性状，か ぶり厚さおよび鉄筋の間隔にも影響されることを考慮す ると，かぶりコンクリートのねじり耐力に及ぼす影響は 複雑であるが，無視できない，本解析ではせん断流の通 路の中心は図一2（e）に示すように考え，せん断流の通 路厚 $\left(t_{d}\right)$ の中心を流れるとした，すなわち，部材の表 面から $t_{d} / 2$ の距離である. かぶりコンクリートの厚さ

(六) をコンクリート表面からスターラップの中心線ま での距離と仮定すると, かぶりコンクリートのはく離は $\bar{c} / t_{d} \geqq 1$ のときに起こると考えた.

c ）破壊形式の分類とせん断ひずみの取扱い

$T / M$ を変数として曲げ・せん断とねじりの組合せ荷 重下の RC 部材のひびわれ性状を観察すると ${ }^{91}, T / M$ が 0.6 付近の荷重の組合せのもとではりの上面にひびわ れが発生する場合としない場合に分類され， $M / V d$ の 影響をほとんど受けないことがわかった。既往の研究 ${ }^{15)}$ では，上面の軸方向鉄筋が引張応力を受けるとき，この 上面にひびわれが発生するとして， $\varepsilon_{u}=0$ でこの上面の ひびわれの有無による破壊性状を分類している場合が多 い. 本解析でも式 (13) において $\varepsilon_{t t}=0$ とおき, 上面の ひびわれ性状にはせん断力（ $V)$ の影響はきわめて少な いことから $V=0$ として $T / M$ を求めると,

$(T / M)_{\mathrm{lim}}=2 \tan \alpha^{l} /\left(1+d_{1} / b_{1}\right)$

となり， $\alpha^{l}=45^{\circ}$ として，この $(T / M)_{\mathrm{lim}}$ によって破壊形 式を分類した。すすなわち， $T / M<(T / M)_{\mathrm{um}}$ の条件下で 上面にはひびわれは生じず，この面でのせん断ひずみ $\left(\gamma^{t}\right)$ は，ひびわれの生じた面でのせん断ひずみよりき わめて小さく, 0 として式 (16) （25）を取り扱った.

（8）解析の適用限界と解析のフローチャート

本解析では曲げ・せん断とねじりを受ける鉄筋コンク リート部材の終局耐力は, その部材がもつねじり耐力に よって決定されることに基づいており，モデルとして立 体トラスモデルを用い，ひびわれ性状の影響をつり合い 条件およびひずみの適合条件に入れて解析を行ってい る. 解析の適用限界は表一1に示すとおりである.なお, 各面のひびわれ角度が $70^{\circ}$ 以上 $\left(T / V b_{1} \leqq 1.07\right)$ では せん断ひずみは生じないとし，0として解析を行った。

解析のフローチャートを図一7に示した。せん断流の 通路厚と斜めひびわれ間のコンクリートの強度およびひ ずみの低減係数は trial and errorによって求めた.

\section{4. 実験結果と解析結果の比較検討}

\section{(1) 実験概要 21,91}

供試体は図一8に示す中実矩形断面である.コンク リートの圧縮強度は $200 \mathrm{kgf} / \mathrm{cm}^{2}$ おび $350 \mathrm{kgf} / \mathrm{cm}^{2}$ の 2 種, 軸方向鉄筋量は軸方向鉄筋比 $\left(p_{l}=2\left(A_{s}+A_{s}^{\prime}\right) /(b\right.$ d)）にして $1.9 \%$ および $3.0 \%$ の 2 種に，また腹鉄筋 量は腹鉄筋比 $\left(p_{v}=A_{h} /(b s)\right)$ にして $0.3,0.6,1.3$ お よび $2.0 \%$ の 4 種に変えて行った。載荷方法は図一9に 示すように供試体にねじり載荷バンドを $\mathrm{PC}$ ボルトで 取り付け，支点を部材中心軸方向から偏心させることに

\section{表一1 解析の適用限界}

\begin{tabular}{|c|c|c|}
\hline$T / M<(T / M))_{i}$ & $\begin{array}{c}T / V_{b} \leq 1.07 \\
\alpha^{r} \geq 70^{\circ}\end{array}$ & $\begin{array}{c}T / b_{1} \leq 0.285 \\
\alpha^{b} \geq 70^{\circ}\end{array}$ \\
\hline$Y_{t}=0$ & $Y_{r}=0$ & $Y_{b}=0$ \\
\hline
\end{tabular}




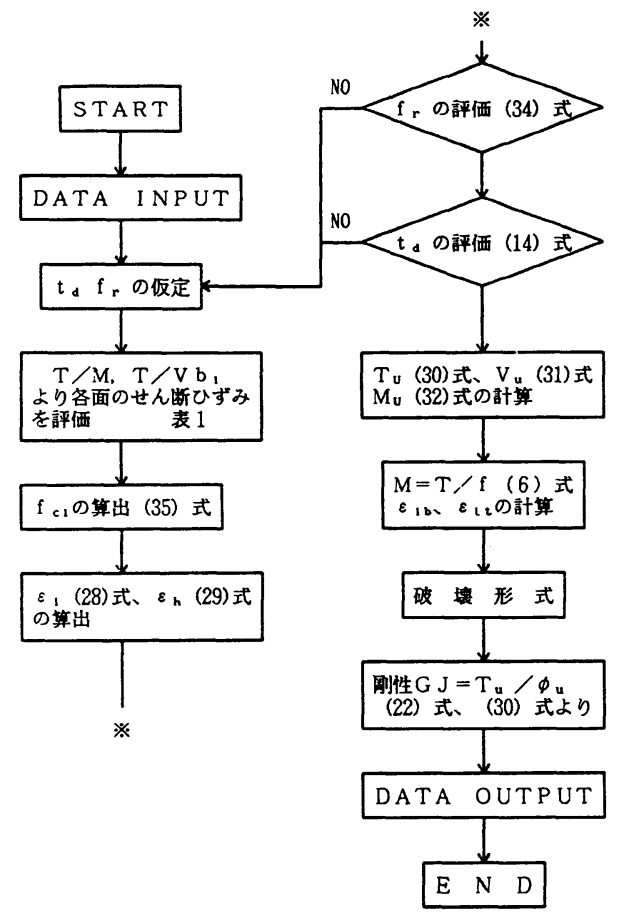

図一7 解析のフローチャート

よりねじりモーメントを作用させた.

\section{（2）実験值と解析值の比較}

実験値と解析値の比較を表一2に示した。この結果に 基づき，終局ねじりモーメンドに関する実験值と解析

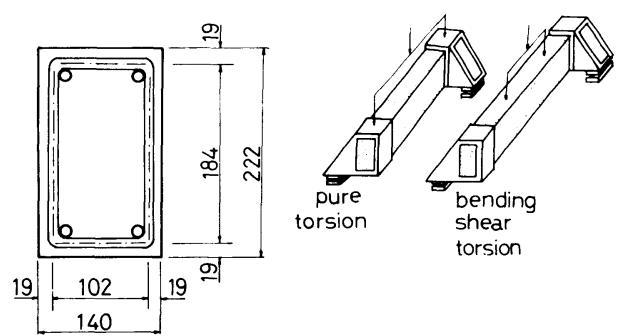

図一8 供試体の断面寸法 図一9 載荷方法 $(\mathrm{mm})$

値の比較検討を図一10に示した。図中には児島 ${ }^{131}$, Klus $^{14)}$ の純ねじり，曲げ・せん断およびねじりを受け る RC 部材の載荷試験結果も引用してある. 実験值と 解析値の比の平均は 1.05 であり, 変動係数は $17 \%$ で あった. $T / M$ が 0.3 の領域では $(T / M)_{\text {lim }}$ より小さく, 上面に圧縮部が形成され，ひずみの適合条件で上面のせ ん断ひずみを 0 として解析することにより，本来のトラ スモデルの仮定と異なる領域でも比較的よい精度で実験 值を推測することができると思われる. 終局時のねじり 剛性の解析值と実験値の比較を図一11に示した. Lampert $^{15)}$ および $\mathrm{Yu}^{16)}$ は曲げせん断およびねじりを受 ける場合の終局時のねじり剛性は $T / M, T / V b_{1}$ の影 響をほとんど受けないと仮定しているが, 今回の解析結

*ここでいう「終局ねじりモーメント」は鉄筋の降伏あるい は斜めひびわれ間の斜め圧縮部コンクリート圧壊時におけ るねじりモーメントである.

\section{表一2 実験値と解析値の比㜞}

\begin{tabular}{|c|c|c|c|c|c|c|c|c|c|c|c|c|}
\hline $\mathrm{Na}$ & $T / M$ & $\begin{array}{c}\mathrm{M} / \mathrm{V} \\
(\mathrm{cm})\end{array}$ & (képie & $\begin{array}{l}p_{1} \\
\text { (\%) }\end{array}$ & (9) & $\begin{array}{c}T=\operatorname{cost} \\
(t, m)\end{array}$ & $\begin{array}{c}T_{\text {a cat }} \\
(t, \omega)\end{array}$ & $\mathrm{T}_{\mathrm{ur}} / \mathrm{T}_{\mathrm{uc}}$ & $\begin{array}{l}\mathrm{G} \mathrm{G}_{\mathrm{TESPT}} \\
\text { (t. m) }\end{array}$ & $\begin{array}{l}\mathrm{GK} \mathrm{cat} \\
\text { (t. mi) }\end{array}$ & $\begin{array}{l}\text { td } \\
\text { (cal) }\end{array}$ & Pailure Mode \\
\hline 1 & $\infty$ & - & 185 & 1.9 & 0.3 & 0.470 & 0.433 & 1.08 & 12.2 & 4.64 & 3.78 & LE-VE-HY \\
\hline 2 & $\infty$ & - & 216 & 1.9 & 0.3 & 0.576 & 0.471 & 1.2 & 10.7 & 5.02 & 3.57 & LE- UE-HY \\
\hline 3 & $\infty$ & $=$ & 185 & 1.9 & 0.6 & 0.520 & 0.537 & 0.97 & 11.4 & 5.40 & 4.62 & LE-VE-HY \\
\hline 4 & $\infty$ & - & 185 & 1.9 & 1.3 & 0.660 & 0.576 & 1.15 & 12.5 & 5.56 & 5.72 & $L E-U E-H E$ \\
\hline 5 & $\infty$ & - & 216 & 1.9 & 1.3 & 0.680 & 0.660 & 1.03 & 12.2 & 6.75 & 4.93 & LE-UE-HY \\
\hline 6 & 0.15 & 47.5 & 207 & 1.9 & 0.6 & 0.232 & 0.254 & 0.91 & 8.8 & 4.59 & 5.92 & LY-UE-HY \\
\hline 7 & 0.3 & 38.0 & 209 & 1.9 & 0.6 & 0.416 & 0.324 & 1.28 & 15.6 & 4.80 & 5.41 & LY-UE-HY \\
\hline 8 & 0.3 & 47.5 & 195 & 1.9 & 0.3 & 0.397 & 0.265 & 1.50 & 11.8 & 4.03 & 4.69 & LY-UE-HY \\
\hline 9 & 0.3 & 47.5 & 195 & 1.9 & 0.6 & 0.392 & 0.341 & 1.15 & 9.8 & 4.78 & 5.42 & LY-UE-HY \\
\hline 10 & 0.3 & 47.5 & 201 & 1.9 & 1.3 & 0.450 & 0.395 & 1.14 & 10.2 & 5.24 & 6.29 & LY-UE-HY \\
\hline 11 & 0.3 & 53.4 & 201 & 1.9 & 0.6 & 0.380 & 0.363 & 1.05 & 27.7 & 5.00 & 5.31 & LY-UE-HY \\
\hline 12 & 0.6 & 47.5 & 201 & 1.9 & 0.6 & 0.540 & 0.430 & 1.26 & 11.8 & 5.57 & 5.12 & LY-UE-HY \\
\hline 13 & 0.6 & 47.5 & 200 & 1.9 & 1.3 & 0.591 & 0.481 & 1.23 & 12.9 & 5.53 & 6.32 & LY-UE-HY \\
\hline 14 & 0.6 & 47.5 & 223 & 1.9 & 1.3 & 0.613 & 0.516 & 1.19 & 7.7 & 6.81 & 5.47 & LY-UE-HY \\
\hline 15 & 1.2 & 38.0 & 216 & 1.9 & 0.6 & 0.600 & 0.496 & 1.23 & 10.7 & 5.49 & 4.56 & $L E-V E-H Y$ \\
\hline 16 & 1.2 & 38.0 & 223 & 1.9 & 1.3 & 0.670 & 0.568 & 1.18 & 10.9 & 6.37 & 5.07 & LE-VE-HY \\
\hline 17 & 1.2 & 47.5 & 203 & 1.9 & 0.3 & 0.371 & 0.388 & 0.96 & 10.7 & 4.50 & 3.86 & $L E-U E-H Y$ \\
\hline 18 & 1.2 & 47.5 & 2003 & 1.9 & 0.6 & 0.527 & 0.492 & 1.07 & 11.8 & 5.36 & 4.63 & LE-VE-HY \\
\hline 19 & 1.2 & 47.5 & 180 & 1.9 & 1.3 & 0.579 & 0.490 & 1.18 & 11.6 & 5.05 & 5.96 & LE-UE-HY \\
\hline 20 & 1.2 & 53.4 & 218 & 1.9 & 0.6 & 0.545 & 0.525 & 1.04 & 12.1 & 5.68 & 4.48 & LE-UE-HY \\
\hline 21 & 1.2 & 53.4 & 218 & 1.9 & 1.3 & 0.618 & 0.585 & 1.06 & 9.8 & 6.41 & 5.07 & LE-UE-HY \\
\hline 22 & $\infty$ & - & 218 & 3.0 & 1.3 & 0.675 & 0.691 & 0.98 & 9.7 & 7.40 & 5.04 & LE-UE-HY \\
\hline 23 & $\infty$ & $=$ & 218 & 3.0 & 1.3 & 0.670 & 0.691 & 0.97 & 11.5 & 7.40 & 5.04 & LE-UE-HY \\
\hline 24 & $\infty$ & - & 345 & 3.0 & 1.3 & 0.820 & 0.958 & 0.86 & 13.1 & 10.38 & 4.16 & LE-UE-HY \\
\hline 25 & $\infty$ & - & 208 & 3.0 & 2.0 & 0.656 & 0.672 & 0.98 & 12.5 & 6.78 & 5.87 & LE-UE-KE \\
\hline 26 & $\infty$ & $=$ & 345 & 3.0 & 2.0 & 0.930 & 1.036 & 0.91 & 13.9 & 10.80 & 4.69 & LE-VE-HY \\
\hline 27 & 0.3 & 47.5 & 216 & 3.0 & 1.3 & 0.499 & 0.374 & 1.34 & 25.3 & 5.46 & 5.47 & LE-UE-HY \\
\hline 28 & 1.2 & 47.5 & 218 & 3.0 & 0.6 & 0.485 & 0.531 & 0.91 & 12.8 & 6.04 & 4.68 & LE-UE-HY \\
\hline 29 & 1.2 & 47.5 & 218 & 3.0 & 1.3 & 0.539 & 0.597 & 0.90 & 13.4 & 6.88 & 5.23 & LE-UE-HY \\
\hline$\frac{.0}{30}$ & 1.2 & 47.5 & 330 & 3.0 & 1.3 & 0.730 & 0.812 & 0.90 & 16.3 & 9.54 & 4.38 & LE-UE-HY \\
\hline 31 & 1.2 & 47.5 & 200 & 3.0 & 2.0 & 0.570 & 0.588 & 0.97 & 9.3 & 6.31 & 6.09 & LE-UE-HY \\
\hline 32 & 1.2 & 47.5 & 218 & 3.0 & 2.0 & 0.660 & 0.615 & 1.07 & 9.6 & 6.64 & 5.96 & LE-VE-HY \\
\hline 33 & 1.2 & 47.5 & 339 & 3.0 & 2.0 & 0.787 & 0.854 & 0.89 & 15.4 & 9.96 & 4.90 & LE-UE-HY \\
\hline 34 & 0.3 & 47.5 & 355 & 1.9 & 0.3 & 0.440 & 0.355 & 1.24 & 12.0 & 5.32 & 3.92 & LY-VE-BY \\
\hline 35 & 0.3 & 47.5 & 355 & 1.9 & 0.6 & 0.410 & 0.482 & 0.85 & 13.3 & 6.86 & 4.37 & LY-UE-HY \\
\hline 36 & 0.3 & 47.5 & 355 & 1.9 & 1.3 & 0.470 & 0.567 & 0.83 & 14.5 & 8.29 & 4.73 & $L Y-U E-H Y$ \\
\hline
\end{tabular}

(j) L:Longi tudinal bars at botton. U:Longitudinal bars at top. H:Stirrup E:Elastic, Y:Yielding. 


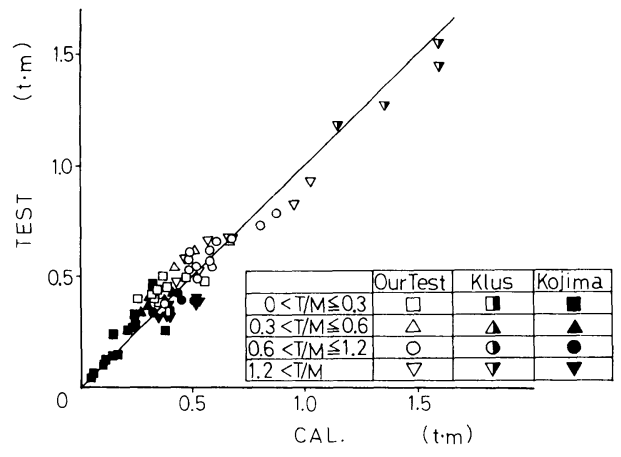

図一10 終局ねじりモーメント

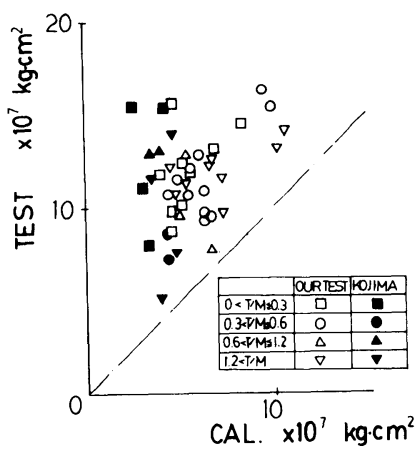

図一11 終局時のねじり剛性

果からも同様の結論が得られた。 今回の実験は荷重制御 型試験機で行ったため，明瞭なねじりモーメントとねじ り変形の関係が得られなかったが, 解析值は大略曲げ・ せん断およびねじりを受ける部材の終局時におけるねじ り剛性を定性的にとらえていると思われた。なお，解析 值が実験値より小さくなったのは，各荷重段階に本解析 を適用して求めた図一12に示すように，解析では最初 から十分にひびわれが入った状態を想定するトラスモデ ルに基づいているが，実際の中実矩形断面部材では高い 荷重に到達するまではひびわれが十分に入りきらないこ とが原因と思われた。

\section{5. 結 語}

曲げ・せん断とねじりを同時に受ける鉄筋コンクリ一 卜部材の耐力および変形性状を知る目的で行ったもので あり，得られた結果を要約すると以下のとおりである.

（1）ねじりを含む組合せ荷重を受ける鉄筋コンク リート部材において，作用ねじりモーメントおよび作用 せん断力をせん断流としてとらえ，斜めひびわれ間のコ ンクリートは，これを横切る軸方向鉄筋およびスター ラップの影響によって一軸状態のコンクリートとは異 なった挙動をとり，このひびわれ間のコンクリートの最 大応力およびこのときのひずみは一軸状態より小さくな

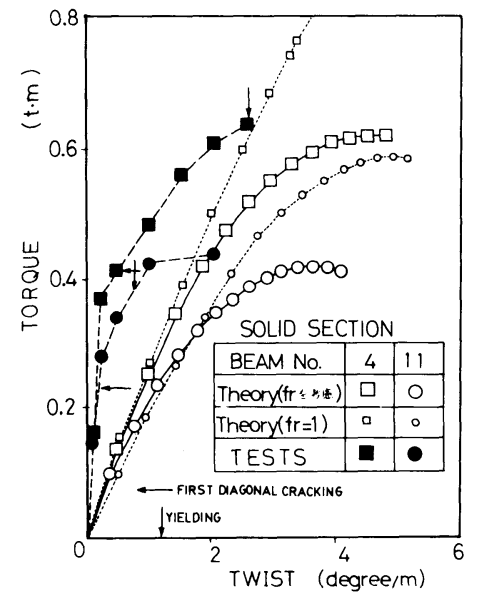

図一12 ねじりモーメントとねじり角の関係

ると考えることによって，この種部材の終局時の挙動を 評価できる。

（2）立体トラス理論ははり断面の四面上に斜めひび われが存在する場合を対象として発展したものであり, ねじりが曲げ・せん断に比べて卓越する領域において適 用可能であるとされてきたが，解析にあたり，ひずみの 適合条件式に上，下面および側面のせん断ひずみ性状を 考虑することによって曲げ・せん断がねじりに比べて卓 越する領域でも適用が可能となる.

（3）終局時のねじり剛性は, ねじりと曲げの比率, ねじりとせん断の比率の影響をほとんど受けず, 鉄筋比

(軸方向鉄筋比, 腹鉄筋比) およびコンクリートの圧縮 強度の影響を受けることが, 実験値および解析值より得 られた。

（4）図一7に示す解析手順により, 曲げ・せん断お よびねじりを同時に受ける鉄筋コンクリート部材の耐 力, ねじり剛性に関する合理的な算定が可能であると思 われる。

謝辞：本研究を進めるにあたり,船越 稔博士(法 政大学教授) および Thomas T. C. Hsu 博士 (Houston 大学教授）より有益なご助言とご援助を賜わりました。 また児島孝之博士（立命館大学教授）からは貴重な実験 資料のご援助をいただきました。ここに深く謝意を表し ます.

なお，本研究には文部省科学研究費補助金が授与され ました。

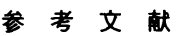

1) 中田慎介：1968 年十勝沖地震後におけるコンクリート建 築構造物の耐震対策, コンクリート工学, Vol. 20, No.9, 
pp. 6 9, 1982 年 9 月.

2) 船越 稔・岡本享久：RC 梁の終局耐力に及ぼすねじり の影響, セメント技術年報, Vol. 35, pp. 463 466, 1981 年.

3) Elfgren, L., Karlsson, I. and Losberg, A. : Torsionbending-Shear interaction for concrete Beams, Proceedings of the American Society of Civil Engineers, Vol. 100, No. ST. 8, pp. 1657 1675, Aug. 1974.

4) Ewida, A. A. and McMullen, A.E. : Torsion-shearflexure interaction in reinforced concrete members, Magazine of Concrete Research, Vol.33, No.115, pp. 113 122, June 1981.

5) Michael P. Collins, Denis Mitchell : Shear and Torsion Design of Prestressed and Non-Prestressed Concrete Beams, PCI Journal, Vol.25, No.5, pp. $32 \sim 100$, Sept. -Oct. 1980.

6) Bruno Thürlimann : Torsional Strength of Reinforced and Prestressed Concrete Beams...... CEB Approach, ACI, SP-59, pp. 117 143, 1979.

7）岡村 甫・前川宏一：弾塑性破壊モデルに基づくコンク リートの平面応力構成則, コンクリート工学, Vol. 21, No. 5 (No. 83.5-1), pp. 87 99, 1983.

8）岡本享久・山岡 暁：ねじりを含む組合せ荷重を受ける コンクリート部材の耐力および変形性状に関する研究, セメント技術年報, Vol. 37, pp. 479 482, 1983.

9）船越 稔・岡本享久・舟橋政司：曲げ・せん断およびね じりを受ける RC 部材の力学的特性, セメント技術年報,
Vol. 36, pp. 462 465, 1982.

10) Thomas T.C. Hsu and Mo, Y.L. : Softneing of Concrete in Torsional Members, University of Houston, Civil Engineering Department, Research Report, pp. 1 107, March 1983.

11) Vecchio, F. and Collins, M. P. : Stress-Strain Characteristics of Reinforced Concrete in Pure Shear, IABSE Collequuim Advanced Mechanics No. 115, pp. 113 122, June 1981 .

12）泉 満明：コンクリート部材の終局ねじり強度の算定と 設計法に関する研究, 土木学会論文報告集, No. 305, pp. 111 124, Jan. 1981 年.

13）児島孝之・高木宣章・和田教志：鉄筋コンクリート部材 の変形適合㸚じりに関する一実験, 第 6 回日本コンクリー 卜工学年次講演会論文集, Vol. 6, pp. 533 536, 1984.

14) Klus, J.P. : Ultimate Strength of Reinforced Concrete Beams in Combined Torsion and Shear, ACI Journal, March, pp. 210 215, 1968.

15) Paul Lampert: Postcracking Stiffness of Reinforced Concrete Beams in Torsion and Bending, ACI, SP 35, pp. 385 433, 1971.

16) Stephen Sandegren and Yu, C. W. : Torsional Stiffness of Reinforced Concrete Rectangular Memembers, Magazine of Concrete Research, Vol.31, No.109, pp.193 201, December 1979.

(1984.9.28 - 受付) 